\title{
AMPLIFIKASI GENE mtDNA CO1 MURAENESOCIDAE DARI PERAIRAN KOTA TARAKAN DENGAN TEKNIK PCR
}

\section{AMPLIFICATION OF THE mtDNA CO1 GENE OF MURAENESOCIDAE FISH FROM TARAKAN WATER WITH PCR METHODE}

\author{
Sumarlin $^{* 1}$, Clara Yovilan Moq ${ }^{1}$, Syamsidar Gaffar ${ }^{2}$, dan M. Gandri Haryono ${ }^{2}$ \\ 1. Prodi Teknologi Hasil Perikanan, UBT \\ 2. Prodi Manajemen Sumberdaya Perairan, UBT \\ *korespondensi, e-mail:sumar.borneo@gmail.com
}

\begin{abstract}
ABSTRAK
Muraenesocidae atau di Tarakan lebih dikenal dengan sebutan Ikan Ose merupakan ikan komersil yang tersebar secara luas di laut Indo-west pacific. Di Indonesia Muraenesocidae tersebar dari pulau Sumatra, Kalimantan, dan Sulawesi. Dengan penyebaran yang begitu luas sayangnya informasi genetik ikan Ose masih sangat terbatas. Penelitian ini dilakukan untuk mengisolasi dan mengamplifikasi gen mtDNA CO1 Muraenesocidae dari perairan Kota Tarakan. Metode penelitian yang dilakukan meliputi isolasi genom mtDNA CO1 dengan mengikuti petunjuk Quick-DNA Tissue/Insect Miniprep Kit. Dilanjutkan dengan amplifikasi untai gen mtDNA CO1 menggunakan 4 primer cocktail. Kemudian visualisasi produk PCR dengan menggunakan teknik gel elektroforesis. Terdapat dua jenis ikan yang dijadikan sampel pada penelitian ini, yaitu Ikan ose dengan perut berwarna kuning (Ose-K) dan Ikan ose dengan perut berwarna hitam $(\mathrm{Ose}-\mathrm{H})$. Ekstrak gen mtDNA Ose-K memiliki konsentrasi $67.3 \mathrm{ng} / \mu \mathrm{l}$ dengan nilai rasio $\mathrm{A}_{260 / 280}$ diperoleh 1.94, dan konsentrasi untuk ekstrak gen mtDNA sampel Ose-H diperoleh $84.5 \mathrm{ng} / \mu \mathrm{l}$ dan 1.97 untuk nilai rasio $\mathrm{A}_{260 / 280}$. Hasil visualisasi produk PCR diperoleh pita tunggal untuk masing-masing sampel dengan panjang basa sekitar $700 \mathrm{bp}$.
\end{abstract}

Kata kunci: gen mtDNA CO1, Ikan Ose, pita DNA, rasio $A_{260 / 280}$

\begin{abstract}
Muraenesocidae fish, which local people are better known as Ose Fish, is a commercial fish widely distributed in the Indo-West Pacific Sea. In Indonesia, Muraenesocidae fish are spread from the islands of Sumatra, Kalimantan, and Sulawesi. With such a widespread, unfortunately, the genetic information of this fish is still minimal. This research was conducted to isolate and amplify the mtDNA CO1 gene of Muraenesocidae fish from Tarakan City's waters. The method included isolation of the mtDNA CO1 genome by following the Quick-DNA Tissue/Insect Miniprep Kit instructions. This step was followed by amplification of mitochondrial DNA gene with cocktails of 4 primers. Next, the PCR product was detected using gel electrophoresis. There are two types of fish in this research: yellow-bellied (Ose-K) and black-bellied (Ose-H). The samples concentration was obtained at $67.3 \mathrm{ng} / \mu \mathrm{l}$ and $84.5 \mathrm{ng} / \mu \mathrm{l}$, while the ratio on $\mathrm{A}_{260 / 280}$ was 1.94 and 1.97, respectively, for Ose-K and Ose-H. The PCR product visualization revealed a single band for each sample with an average base length of about $700 \mathrm{bp}$.

Keyword: mtDNA COI gene, Ose Fish, DNA Band, A260/280 ratio
\end{abstract}




\section{PENDAHULUAN}

Indonesia merupakan negara tropis dengan tingkat biodeversitas biota laut tertinggi dibandingkan dengan negara tetangga lainnya yang berada di gugus wilayah Indo-Pasifik (Nurilmala et al. 2017). Jumlah yang melimpah menjadikan perikanan sebagai salah satu sektor penunjang ekonomi yang penting sekaligus sebagai salah satu sumber ketahanan pangan nasional (Abdullah et al. 2017). Muraenesocidae (Ikan Ose) merupakan ikan komersil penting dan menjadi komoditi ekspor di Indonesia, dan di Kota Tarakan ikan ini lebih cenderung di ekspor ke negara tetangga yaitu Malaysia melalui wilayah Tawau, Sabah. Meskipun kelimpahan Ikan Ose sangatlah besar namun informasi dan publikasi tentang ikan Ose masih sangat terbatas. Padahal informasi terkait biota laut perairan maritime sangat diperlukan ditengah kondisi laut yang mengalami penurunan kualias akibat pencemaran lingkungan serta adanya overfisihing dan illegal fisihing memicu penurunan populasi bahkan terancam mengalami kepunahan (Abdullah et al. 2017). Saat ini telah banyak dilakukan penelitian untuk menggali informasi biota laut nusantara terutama informasi genetik berbasis DNA barcoding, yaitu suatu teknik mengidentifikasi suatu organisme dengan menggunakan marker DNA salah satunya gene mitokondria cytochrome oxidase subunit I (COI). Beberapa contoh penelitian DNA barcoding biota laut diantaranya identifikasi ikan Hiu (Prehadi et al. 2015), Ikan Kerapu (Jefri et al. 2015), Ikan Hias (Fahmi et al. 2017), Autentikasi Produk Hasil Perikaan (Abdullah et al. 2017; Abdullah et al. 2019; Madduppa et al. 2014; Nurilmala et al. 2017; Maulid et al. 2015), Larva Ikan (Abdullah et al. 2017; Wibowo et al. 2017; Wibowo et al. 2018), jenis kerang (Tindi et al. 2017) bahkan Manggrove (Riyantini et al. 2014) telah dilakukan analisis molekuler. Untuk wilayah Kalimantan Utara, penelitian tentang DNA barcoding telah dilakukan pada biota laut ikan nomei (Nugroho et al. 2017), namun belum ada informasi genetik yang tersedia terkait ikan Ose. Sehingga penelitian tentang DNA barcoding ikan ose penting dilakukan. Penelitian ini adalah penelitian pendahuluan dari rangkaian tahapan DNA barcoding yang terbatas pada amplifikasi gen mt DNA COI ikan ose.

\section{METODOLOGI}

\section{Waktu dan tempat}

Penelitian ini dilaksanakan di Laboratorium Biologi Fakultas Perikanan dan Ilmu Kelautan UBT. Waktu penelitian ini dilaksanakan selama 3 bulan dimulai Mei hingga Juli 2020. Penelitian dilaksanakan dua tahap yaitu pengambilan sampel di lapangan dan analisis DNA di laboratorium.

\section{Alat dan Bahan}

Alat yang digunakan dalam penelitian ini adalah alat-alat gelas, kalkulator, alat tulis, timbangan, vortex, mikrosentrifus, mikropipet, tip pipet, Biofuge Primo $R$ Centrifuge, heating block, horizontal elektroforesis (Power Pac Basic $^{\text {TM }}$, USA), Spektrofotometer UV- Vis (Pharmacia Biotech), thermo cyler (Agilent Surecycler 8800), serta perangkat lunak Mega X, Seq Scanner v.2.0 dan Bio Edit.

Bahan yang digunakan dalam penelitian adalah sampel jaringan otot ikan pari totol biru, alcohol 70\%, Agarosa, buffer Tris-EDTA (TE) $\mathrm{pH} 8$, Tris-BoratEDTA (TBE) 1x, marker $100 \mathrm{pb}$ (Invitrogen), kit ZR Tissue \& Insect DNA miniprep $^{\mathrm{TM}}$, MyTaq HS Red Mix (Bioline), primer, kloroform, aseton, etidium bromide, loading dye, serta low mass leader.

\section{Metode}

\section{Ekstraksi dan Amplifikasi DNA}

Ekstraksi DNA berasal dari potongan kecil tubuh ikan Ose (otot). Ekstraksi DNA berasal dari potongan kecil tubuh ikan pari totol biru. Proses 
pencucian alkohol pengawet dilakukan dengan merendam sekitar 10 gr potongan otot dalam etanol $70 \%$. Proses ekstraksi DNA sampel mengikut petunjuk ZR Tissue \& Insect DNA miniprep ${ }^{\mathrm{TM}}$ (Zymo Research, D6016). Proses amplifikasi PCR menggunakan kit MyTaq HS Red Mix (Bioline) dengan komposisi: $\mathrm{ddH}_{2} \mathrm{O} \quad 9.5$ $\mu \mathrm{L}$, MyTaq Red Mix 2x $12.5 \mu \mathrm{L}$, dan primer masing-masing $10 \mu \mathrm{M}$ menggunakan 4 primer cocktail berdasarkan Canadian Center for DNA Barcoding (CCDB), 2006

$\begin{array}{clll} & \text { VF2 } & \text { TGTAAAACGACGGCCAGTC } \\ \text { For } & \text {-t1 } & \text { AACCAACCACAAAGACATT } \\ \text { war } & & \text { GGCAC } \\ \text { d: } & \text { Fish } & \text { TGTAAAACGACGGCCAGTC } \\ & \text { F2_t } & \text { GACTAATCATAAAGATATC } \\ & 1 & \text { GGCAC } \\ & \text { Fish } & \text { CAGGAAACAGCTATGACAC } \\ \text { Rev } & \text { R2_ } & \text { TTCAGGGTGACCGAAGAAT } \\ \text { erse } & \text { t1 } & \text { CAGAA } \\ : & \text { FR1 } & \text { CAGGAAACAGCTATGACAC } \\ & \text { d_t1 } & \text { CTCAGGGTGTCCGAARAAY } \\ & & \text { CARAA }\end{array}$

DNA diamplifikasi dengan PCR menggunakan kit 2x MyTaq HS Red Mix (Bioline). Total volume yang digunakan untuk amplifikasi yaitu $25 \mu \mathrm{l}$, yang terdiri atas $9.5 \mu \mathrm{lddH} 2 \mathrm{O}, 12.5 \mu \mathrm{l}$ 2x MyTaq Red Mix, $1 \mu \mathrm{l}$ DNA template dan 0,5 $\mu \mathrm{l}$ volume dari tiap primer $10 \mu \mathrm{M}$. Amplifikasi DNA menggunakan mesin PCR Tpersonal (Biometra) dengan pengaturan suhu sebagai berikut: predenaturasi pada suhu $96{ }^{\circ} \mathrm{C}$ selama 3 menit, denaturasi pada suhu $94^{\circ} \mathrm{C}$ selama 10 detik dilakukan sebanyak 35 siklus, annealing pada suhu $50^{\circ} \mathrm{C}$ selama 30 detik dan dilakua sebanyak 35 siklus, elongasi pada suhu $72{ }^{\circ} \mathrm{C}$ selama 45 detik sebanyak 35 siklus dan satu siklus perpanjangan akhir pada suhu $72{ }^{\circ} \mathrm{C}$ selama 2 menit kemudian didiamkan pada suhu $4{ }^{\circ} \mathrm{C}$ selama 5 menit. Produk PCR dianalisis menggunakan metode elektroforesis gel agarosa $1 \% \mathrm{~b} / \mathrm{v}$ dengan mengambil $3 \mu \mathrm{L}$ sampel hasil PCR dan $3 \mu \mathrm{L}$ DNA ladder $100 \mathrm{pb}$ dimasukkan ke dalam sumur yang terbentuk dari sisir yang dijalankan dalam buffer TBE (Tris-Boric Acid-EDTA) 1x pada tegangan $120 \mathrm{~V}$ selama 20 menit yang dilanjutkan dengan visualisasi pada alat UV Transiluminator (Gel Doc) (Sulistiowati et al. 2020)

\section{HASIL DAN PEMBAHASAN}

Basis data dalam analisis molekuler adalah sekuen DNA. Terdapat tiga jenis DNA pada sel eukariot yaitu DNA Inti (nuDNA), DNA mitokondria (mtDNA), dan DNA klorofil atau plastid pada tumbuhan. Pada Ikan, jenis DNA yang umum dugunakan dalam analisa molekuler adalah sekuen genom mtDNA. Salah satu Gen penyandi dalam genom mtDNA yang paling umum digunakan dalam analisa molekuler adalah Gen cytochrome oxidase subunit I (CO1). Pemilihan gen ini dikarenakan sifat-sifat istimewanya seperti jarang mengalami peristiwa mutasi baik delesi maupun insersi pada sekuennya, mempu nyai daerah bersifat conserve (lestari) yang menjadi pijakan dalama analisis molekuler seperti DNA barcoding (Hebert et al. 2003). Selain itu, gen ini dapat digunakan untuk merekonstruksi filogenetik pada cabang evolusi tingkat spesies (Palumbi 1996).

Penelitian sebelumnya telah melaporkan keberhasilan amplifikasi gen mtDNA CO1 ikan dengan primer universal rekomendasi dari CCDB (Fields et al. 2015; Shirley et al. 2015; Reid et al. 2011; Ivanova et al. 2007; Ude et al. 2020; Schmitt et al. 2019; Giovos et al. 2020; Hu et al. 2018; Saha et al. 2019; Zhang et al. 2011; Hinkle 2015; Cardeñosa et al. 2017; Moran et al. 2015), sehingga pada penelitian ini juga menggunakan primer universal yang sama. Ekstraksi dan amplifikasi gen mtDNA COI sampel ikan ose dilakukan pada dua jenis yaitu ose perut kuning (Ose-K) dan Ose Perut hitam (Ose-H) dengan mengambil jaringan otot masing-masing sebanyak 1 gram. Ekstraksi gen mtDNA menggunakan 
metode Zymo research, D6016 dan pada tabel 2. diperoleh data seperti yang dicantumkan

Tabel 1. Data kuantitatif hasil ekstraksi gen mtDNA sampel

\begin{tabular}{llccc}
\hline No. & Nama Sampel & $\begin{array}{c}\text { Konsentrasi } \\
(\mathbf{n g} / \boldsymbol{\mu l})\end{array}$ & $\mathbf{A 2 6 0 / 2 8 0}$ & $\mathbf{A 2 6 0 / 2 3 0}$ \\
\hline 1. & Ose-K & 67.3 & 1.94 & 0.55 \\
2. & Ose-H & 84.5 & 1.97 & 0.53 \\
\hline
\end{tabular}

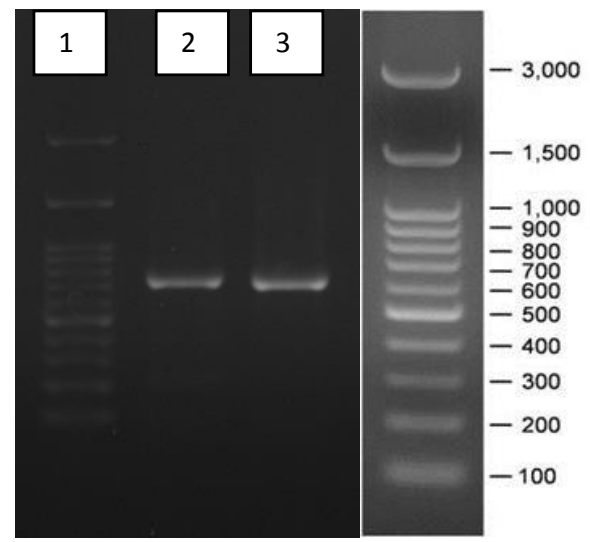

Ket:

1. DNA Ladder

2. Ose-K

3. Ose-H

Gambar 1. Visualisasi produk PCR pad gel agarose

Hasil eksraksi gen mtDNA kedua sampel memberikan konsentrasi yang cukup tinggi dengan nilai sebesar masingmasing untuk Ose-K dan Ose-H adalah $67.3 \mathrm{ng} / \mu \mathrm{l}$ dan $84.5 \mathrm{ng} / \mu \mathrm{l}$. Disisi lain, untuk menetukan tingkat kemurnian hasil ekstraksi mtDNA sampel dapat dilihat dari rasio absorbansi (A) pada panjang gelombang 260/280 nm dan 260/230 nm. Rasio $\mathrm{A}_{260 / 280}$ digunakan untuk menentukan konsentrasi DNA terhadap Protein. DNA menyerap sinar ultraviolet pada panjang gelombang $260 \mathrm{~nm}$, sedangkan protein menyerap sinar UV pada panjang gelombang $280 \mathrm{~nm}$. Tingkat kemurnian DNA hasil isolasi terbaik berada pada nilai $\mathrm{A}_{260 / 280}$ antara 1.8 - 2.0. Semakin mendekati angka 2.0 maka tingkat kemurnian DNA isolat semakin mendekati 100\% (Farmawati et al. 2015; Pratiwi et al. 2020). Pada hasil penelitian ini, kedua sampel baik Ose-K dan Ose-H masing-masing memiliki nilai rasio $\mathrm{A}_{260 / 280}$ mendekati angka 2.0 sehingga tingkat kemurnian DNA isolat kedua sampel ini menghampiri 100\%. Kemurnian
DNA hasil ekstraksi juga dapat ditentukan melalui rasio $\mathrm{A}_{260 / 230}$. Ekstrak DNA dikatakan murnia apabila nilai rasio yang diperoleh berada pada kisaran $2.0-2.2$ Jika nilai rasio yang diperoleh lebih rendah dari nilia ideal tersebut maka dapat dikatakan bahwa ekstrak masih terkontaminasi pelarut sisa proses ekstraksi yang turut andil menyerap panjang gelombang $230 \mathrm{~nm}$ (Gardenia et al. 2011). Pada hasil penelitian ini diperoleh rasio $\mathrm{A}_{260 / 230}$ sebesar 0.55 dan 0.53 untuk ekstrak Ose-K dan Ose-H. Tingkat kemurnian ini masih jauh dibawah nilai ideal $(2.0$ - 2.2) namun, hal ini disebabkan karena pengukuran rasio $\mathrm{A}_{260 / 230}$ masih merupakn ekstrak kasar sehingga antara DNA dan sisa pelarut ekstraksi belum dipisahkan sehingga memberikan andil yang sangat besar dalam memberikan nilai rasio dibawah nilai ideal. Meskipun nilai rasio $\mathrm{A}_{260 / 280}$ masih dibawah nilai yang diharapkan, hasil ekstraksi ini masih dapat digunakan untuk proses amplifikasi (perbanyakan) dengan menggunakan teknik PCR. 
Hasil amplifikasi PCR menunjukkan bahwa kedua gen mtDNA COI memiliki panjang sekuen sekitar 700 pasang basa (pb). Hal ini dapat dikonfirmasi dari hasil elektroforesis $1 \mu \mathrm{l}$ masing-masing produk PCR ke dalam gel $1 \%$ agarose dalam larutan TBE. Reaksi PCR dikatakan berhasil apabila menghasilkan pita DNA tunggal dan tebal. Pada gambar 2 dapat dilihat bahwa hasil PCR pada penelitian ini diperoleh pita DNA tunggal dan tebal sehingga reaksi PCR telah berhasil dilakukan. Ukuran pita DNA hasil PCR dengan panjang sekitar 700 pb juga diperoleh pada penelitian identfikasi bivalvia yang dilakukan oleh Tindi et al (2017), dan ikan nomei yang dilakukan oleh Nugroho et al (2017).

\section{KESIMPULAN DAN SARAN}

\section{Kesimpulan}

Berdasarkan hasil penelitian diperoleh ekstrak gen mtDNA kedua sampel dengan konsentrasi yang cukup tinggi dengan nilai sebesar masing-masing untuk Ose-K dan Ose-H adalah $67.3 \mathrm{ng} / \mu \mathrm{l}$ dan $84.5 \mathrm{ng} / \mu \mathrm{l}$. Kemurnian ekstrak kedua sampel baik Ose-K dan Ose-H masingmasing memiliki nilai rasio $\mathrm{A}_{260 / 280}$ mendekati angka 2.0 sehingga tingkat kemurnian DNA isolat kedua sampel ini menghampiri 100\%. Hasil amplifikasi PCR menunjukkan bahwa kedua gen mtDNA COI memiliki panjang sekuen sekitar 700 pasang basa (pb).

\section{Saran}

Penentuan spesies ikan ose perlu dilakukan dengan teknik DNA barcoding, sehingga penting untuk dilaksanakan penelitian lanjutan meliputi sekuensing gen mtDNA COI ikan ose, dilanjutkan dengan analisis BLAST dan filogenetik.

\section{DAFTAR PUSTAKA}

Abdullah, A., \& Rehbein, H. 2017. DNA barcoding for the species identification of commercially important fishery products in Indonesian markets. International Journal of Food Science and Technology 52(1): p.266-274.

Abdullah, A., Sativa, H.A., Nurhayati, T., \& Nurilmala, M. 2019. Pemanfaatan DNA barcoding untuk ketertelusuran label berbagai produk olahan ikan berbasis surimi komersial. Jphpi 22: p.508-519.

Cardeñosa, D. et al. 2017. A multiplex PCR mini-barcode assay to identify processed shark products in the global trade. PLoS ONE 12(10): p.3-11.

Fahmi, M.R., Kusumah, R.V., Ardi, I., Sinansari, S., \& Kusrini, E. 2017. Dna Barcoding Ikan Hias Introduksi. Jurnal Riset Akuakultur 12(1): p.29.

Farmawati, D., Wirajana, I., \& Chandra Yowani, S. 2015. Perbandingan Kualitas Dna Dengan Menggunakan Metode Boom Original Dan Boom Modifikasi Pada Isolat Mycobacterium Tuberculosis 151. Jurnal Kimia 9(1): p.41-46.

Fields, A.T., Abercrombie, D.L., Eng, R., Feldheim, K., \& Chapman, D.D. 2015. A novel mini-DNA barcoding assay to identify processed fins from internationally protected shark species. PLoS ONE 10(2): p.1-10.

Gardenia, L., \& Koesharyani, I. 2011. Metode Isolasi Deoxyribose Nucleic Acid Bakteri dari Organ Ikan Nila (Oreochromis niloticus). Jurnal Ris. Akuakultur 6(3): p.469-477.

Giovos, I. et al. 2020. Assessing multiple sources of data to detect illegal fishing, trade and mislabelling of elasmobranchs in Greek markets. Marine Policy 112(March).

Hinkle, J. 2015. Proof-of-concept of environmental DNA tools for atlantic 
sturgeon management. : p.46..

Hu, Y., Huang, S.Y., Hanner, R., Levin, J., \& Lu, X. 2018. Study of fish products in Metro Vancouver using DNA barcoding methods reveals fraudulent labeling. Food Control 94: p.38-47.

Ivanova, N. V., Zemlak, T.S., Hanner, R.H., \& Hebert, P.D.N. 2007. Universal primer cocktails for fish DNA barcoding. Molecular Ecology Notes 7(4): p.544-548.

Jefri, E., Zamani, N.P., Subhan, B., \& Madduppa, H.H. 2015. Molecular phylogeny inferred from mitochondrial DNA of the grouper epinephelus spp. In Indonesia collected from local fish market. Biodiversitas 16(2): p.254-263.

Madduppa, H.H., von Juterzenka, K., Syakir, M., \& Kochzius, M. 2014. Socio-economy of marine ornamental fishery and its impact on the population structure of the clown anemonefish Amphiprion ocellaris and its host anemones in Spermonde Archipelago, Indonesia. Ocean and Coastal Management 100: p.41-50.

Maulid, D., \& Nurilmala, M. 2015. Dna Barcoding Untuk Autentikasi Produk Ikan Tenggiri (Scomberomorus Sp). Jurnal Akuatika Indonesia 6(2): p.244388.

Moran, Z., Orth, D.J., Schmitt, J.D., Hallerman, E.M., \& Aguilar, R. 2015. Effectiveness of DNA barcoding for identifying piscine prey items in stomach contents of piscivorous catfishes. Environmental Biology of Fishes 99(1): p.161-167.

Nugroho, E.D., Nawir, D., Amin, M., \& Lestari, U. 2017. Dna barcoding of nomei fish (Synodontidae: Harpadon sp.) in Tarakan Island, Indonesia. AACL Bioflux 10(6): p.1466-1474.

Nurilmala, M., Sari, E.M., Abdullah, A.,
Sudrajat, A.O., \& Ochiai, Y. 2017. Species identification by DNA barcoding and bioprospecting of Indonesian seahorses. The JSFS 85th Anniversary-Commemorative

International Symposium "Fisheries Science for Future Generations" (10032): p.2-3.

Pratiwi, E., \& Widodo, L.I. 2020. Kuantifikasi Hasil Ekstraksi Gen Sebagai Faktor Kritis Untuk Keberhasilan Pemeriksaan Rt Pcr. Indonesian Journal for Health Sciences 4(1): p.1.

Prehadi et al. 2015. DNA barcoding and phylogenetic reconstruction of shark species landed in muncar fisheries landing site in comparison with southern Java fishing port. Biodiversitas 16(1): p.55-61.

Reid, B.N. et al. 2011. Comparing and combining distance-based and character-based approaches for barcoding turtles. Molecular Ecology Resources 11(6): p.956-967.

Riyantini, I., Mulyani, Y., \& Agung, M. 2014. Hubungan Filogenetik Molekuler Beberapa Jenis Mangrove Di Pulau Penjarangan, Ujung Kulon, Provinsi Banten. Jurnal Akuatika Indonesia 5(1): p.245336.

Saha, S. et al. 2019. NEW RECORDS OF THE GOATFISH, UPENEUS VITTATUS (FORSSKAL 1775) AND UPENEUS SUPRAVITTATUS (UIBLEIN AND HEEMSTRA 2010) 
(PRECIFORMES, MULLIDAE), FROM SAINT MARTIN'S ISLAND IN THE BAY OF BENGAL, BANGLADESH. J. Asiat. Soc. Bangladesh, Sci. 2(December): p.161173.

Schmitt, J.D., Emmel, J.A., Bunch, A.J., Hilling, C.D., \& Orth, D.J. 2019. Feeding Ecology and Distribution of an Invasive Apex Predator: Flathead Catfish in Subestuaries of the Chesapeake Bay, Virginia. North American Journal of Fisheries Management 39(2): p.390-402.

Shirley, M.H., Villanova, V.L., Vliet, K.A., \& Austin, J.D. 2015. Genetic barcoding facilitates captive and wild management of three cryptic African crocodile species complexes. Animal Conservation 18(4): p.322-330.

Sulistiowati, S., \& Madduppa, H. 2020. Identifikasi Scatophagus argus yang dipasarkan di Jakarta berdasarkan Analisis Morfologi dan DNA Barcoding. Jurnal Kelautan Tropis.

Tindi, M. et al. 2017. DNA BARCODE DAN ANALISIS FILOGENETIK MOLEKULER BEBERAPA JENIS BIVALVIA ASAL PERAIRAN SULAWESI UTARA BERDASARKAN GEN COI (The
DNA Barcode and molecular phylogenetic analysis several Bivalve species from North Sulawesi Waters based on COI gene). Jurnal Pesisir dan Laut Tropis 1(2): p.32-38.

Ude, G.N. et al. 2020. DNA barcoding for identification of fish species from freshwater in Enugu and Anambra States of Nigeria. Conservation Genetics Resources 12(4): p.643-658.

Wibowo, A., Panggabaian, A.S., Zamroni, A., Priatna, A., \& Yusuf, H.N. 2018. Using Dna Barcode To Improve the Identification of Marine Fish Larvae, Case Study Coastal Water Near Jakarta and Banda Sea, Indonesia. Indonesian Fisheries Research Journal 24(1): p.37.

Wibowo, A., Wahlberg, N., \& Vasemägi, A. 2017. DNA barcoding of fish larvae reveals uncharacterised biodiversity in tropical peat swamps of New Guinea, Indonesia. Marine and Freshwater Research 68(6): p.1079-1087.

Zhang, J. Bin, \& Hanner, R. 2011. DNA barcoding is a useful tool for the identification of marine fishes from Japan. Biochemical Systematics and Ecology 39(1): p.31-42. 